\title{
How Improved Fuel Efficiency May Change U.S. Middle East Policy
}

\author{
by \\ Colonel William F. Ratledge \\ United States Air Force
}

\section{United States Army War College Class of 2012}

\author{
DISTRIBUTION STATEMENT: A \\ Approved for Public Release Distribution \\ is Unlimited
}

This manuscript is submitted in partial fulfillment of the requirements of the Master of Strategic Studies Degree. The views expressed in this student academic research paper are those of the author and do not reflect the official policy or position of the Department of the Army, Department of Defense, or the U.S. Government. 
The U.S. Army War College is accredited by the Commission on Higher Education of the Middle States Association of Colleges and Schools, 3624 Market Street, Philadelphia, PA 19104, (215) 662-5606. The Commission on Higher Education is an institutional accrediting agency recognized by the U.S. Secretary of Education and the Council for Higher Education Accreditation. 


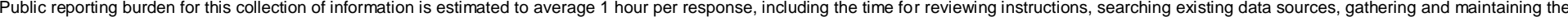

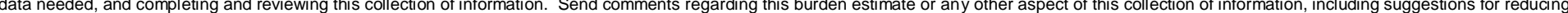

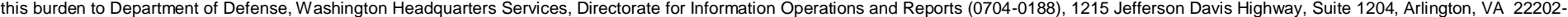

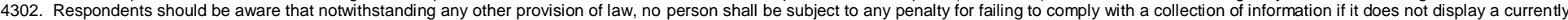
valid OMB control number. PLEASE DO NOT RETURN YOUR FORM TO THE ABOVE ADDRESS.

\section{REPORT DATE $(D D-M M-Y Y Y Y)$ 2. REPORT TYPE \\ . DATES COVERED (From - To)}

14-03-2012

Strategy Research Project

\section{TITLE AND SUBTITLE}

How Improved Fuel Efficiency May Change U.S. Middle East Policy

5a. CONTRACT NUMBER

5b. GRANT NUMBER

5c. PROGRAM ELEMENT NUMBER

6. AUTHOR(S)

Colonel William Ratledge

5d. PROJECT NUMBER

5e. TASK NUMBER

5f. WORK UNIT NUMBER

7. PERFORMING ORGANIZATION NAME(S) AND ADDRESS(ES)

George Teague

8. PERFORMING ORGANIZATION REPORT

Department of National Security and NUMBER

Strategy

9. SPONSORING / MONITORING AGENCY NAME(S) AND ADDRESS(ES)

U.S. Army War College

122 Forbes Avenue

Carlisle, PA 17013

10. SPONSOR/MONITOR'S ACRONYM(S)

11. SPONSOR/MONITOR'S REPORT NUMBER(S)

\section{DISTRIBUTION / AVAILABILITY STATEMENT}

Distribution: A: Approved for public release distribution is unlimited

\section{SUPPLEMENTARY NOTES}

\section{ABSTRACT}

The United States consumes 19 million barrels of oil per day, importing about 9 million. When demand exceeded production capacity in 1970 , foreign countries began supplying petroleum to the U.S. allowing continued expansion of the economy; about $80 \%$ from Canada, Mexico, Central and South America and 20\% from the Middle East. Consequently, foreign oil producing nations retain economic leverage over the United States and often inhibit our government from exercising desired policy. The 1970s OPEC oil embargo against the United States in response to support for Israel is an example. Reducing oil consumption to well within domestic production capacity would eliminate oil producing countries' leverage over the United States, allowing our government to pursue vital interests without interference or the threat of supply disruptions devastating the economy. There are numerous options available such as increased domestic production; reduced consumption; increased utilization of mass transit; producing and driving more fuel efficient vehicles; and alternative energy sources like solar, wind and nuclear power. A combination of policy options may reduce overall U.S. consumption by one-third within five to ten years. Reduced energy consumption would eliminate the need for Middle East oil and potentially change U.S. policy towards and within the Middle East.

\section{SUBJECT TERMS}

petroleum, energy efficiency, bio-diesel, gas tax, fuel consumption

16. SECURITY CLASSIFICATION OF:

\section{a. REPORT} UNCLASSIFED b. ABSTRACT UNCLASSIFED c. THIS PAGE UNCLASSIFED
17. LIMITATION OF ABSTRACT

UNLIMITED
18. NUMBER OF PAGES

26 19a. NAME OF RESPONSIBLE PERSON

19b. TELEPHONE NUMBER (include area code) 



\title{
HOW IMPROVED FUEL EFFICIENCY MAY CHANGE U.S. MIDDLE EAST POLICY
}

\author{
by \\ Colonel William F. Ratledge \\ United States Air Force \\ Professor George Teague \\ Project Adviser
}

This SRP is submitted in partial fulfillment of the requirements of the Master of Strategic Studies Degree. The U.S. Army War College is accredited by the Commission on Higher Education of the Middle States Association of Colleges and Schools, 3624 Market Street, Philadelphia, PA 19104, (215) 662-5606. The Commission on Higher Education is an institutional accrediting agency recognized by the U.S. Secretary of Education and the Council for Higher Education Accreditation.

The views expressed in this student academic research paper are those of the author and do not reflect the official policy or position of the Department of the Army, Department of Defense, or the U.S. Government. 



\section{ABSTRACT}

$\begin{array}{ll}\text { AUTHOR: } & \text { Lieutenant Colonel William F. Ratledge } \\ \text { TITLE: } & \text { How Improved Fuel Efficiency May Change U.S. Middle East Policy } \\ \text { FORMAT: } & \text { Strategy Research Project } \\ \text { DATE: } & 14 \text { March } 2012 \quad \text { WORD COUNT: } 5745 \quad \text { PAGES: } 30 \\ \text { KEY TERMS: } & \begin{array}{l}\text { Petroleum, Energy Efficiency, Bio-Diesel, Gas Tax, Fuel } \\ \text { Consumption, Energy Security }\end{array} \\ \text { CLASSIFICATION: } & \text { Unclassified }\end{array}$

The United States consumes 19 million barrels of oil per day, importing half. When demand exceeded production in 1970, foreign countries began supplying oil allowing economic expansion; about $80 \%$ from Canada, Mexico, Central and South America and $20 \%$ from the Middle East. Consequently, these nations retain economic leverage over the United States and often inhibit our government policy. The 1970s OPEC oil embargo against the United States in response to support for Israel is an example. Reducing oil consumption to domestic production capacity would eliminate oil producing countries' leverage over the United States, allowing our government to pursue vital interests without interference or the threat of supply disruptions. There are numerous options available such as increased domestic production; reduced consumption; increased utilization of mass transit; producing and driving more fuel efficient vehicles; and alternative energy sources like solar, wind and nuclear power. A combination of policy options may reduce overall U.S. consumption by one-third within five to ten years. Reduced energy consumption would eliminate the need for Middle East oil and potentially change U.S. policy towards and within the Middle East. 

HOW IMPROVED FUEL EFFICIENCY MAY CHANGE U.S. MIDDLE EAST POLICY

Our energy resources are not inexhaustible, yet we are permitting waste in their use and production. In some instances, to achieve apparent economies today future generations will be forced to carry the burden of unnecessarily high costs and to substitute inferior fuels for particular purposes. National policies concerning these vital resources must recognize the availability of all of them; the location of each with respect to its markets; the costs of transporting them; the technological developments which will increase the efficiency of their production and use; and the relationships between the increased use of energy and the general economic development of the country.

-Franklin D. Roosevelt ${ }^{1}$

President of the United States

The question for many politicians and citizens alike is: should the United States implement measures to dramatically reduce petroleum consumption and transition to alternative fuels in order to eliminate Middle Eastern economic leverage over U.S. foreign policy? The United States requires vast amounts of energy to conduct business and recreation. "The First World War made all Western governments painfully aware of the importance of oil... The dependence on oil for survival became obvious as the war extended-fought with planes, cars and tanks. . ." Oil quickly rose to a critical national security interest. The United States consumes 19 million barrels of oil per day, while importing about 9 million of those used. When demand exceeded production capacity in 1970, foreign countries supplying petroleum to the United States, allowing continued expansion of the economy, became vital to our survival. America currently imports about $80 \%$ from Canada, Mexico, Central and South America and 20\% from the Middle East. Thus, foreign oil producing nations retain economic leverage over the United States and often inhibit the U.S. government from exercising desired policy. One classic example is the 1973 OPEC oil embargo against the United States and the West in response to U.S. support for Israel. 
Transitioning to alternative fuels and reducing oil consumption to well within domestic production capacity would reduce or eliminate oil producing countries' leverage over the United States, allowing the government to pursue vital interests without foreign interference or the threat of supply disruptions and potential devastating economic impacts. There are numerous options available to reduce consumption; these include: increased utilization of mass transit; producing and driving more fuel efficient vehicles; and alternative energy sources, such as solar, wind and nuclear power. A combination of policy options and conservation could reduce overall U.S. consumption by one-third within five to ten years. This reduced energy consumption would eliminate the need for Middle East oil imports, free the United States from their influence and potentially change U.S. policy towards and within the Middle East. Therefore, Congress should implement domestic and foreign policy designed to reduce petroleum consumption and transition to alternative fuels in order to reduce foreign influence over national security and U.S. foreign policy.

\section{$\underline{\text { National Security }}$}

For over a century oil has been the lifeblood of the American nation. Oil opened economic doors and enabled U.S. industry's rapid expansion. The critical role of oil in U.S. development was noted as early as 1865 when a reporter, J.H.A. Bone, in his book Petroleum and Petroleum Wells stated "From Maine to California it lights our dwellings, lubricates our machinery, and is indispensible in numerous departments of arts, manufactures and domestic life. To be deprived of it now would be setting us back a whole cycle of civilization. To doubt the increased sphere of its usefulness would be to lack faith in the progress of the world." ${ }^{3}$ For the past century maintaining America's oil 
supply has been and continues to be a vital national interest and crucial to national security. As early as 1949 the United States forecast petroleum's importance to survival and chartered the National Petroleum Council to develop an oil policy for America. The National Petroleum Council soon realized, "Oil in increasing quantities will be required in the future to meet the needs of our expanding economy. A prime weapon of victory in two world wars it is a bulwark of our national security." 4

Initial U.S. oil policy was based upon four foundational principles. First and foremost, our nation's security and public welfare demand a robust domestic petroleum industry. Next, a competitive oil industry operating in a free market economy will better serve the public interest. ${ }^{5}$ Third, state and federal government should maintain their existing relationships with the oil industry. Finally, "No government actions specifically affecting the oil industry should be taken without proper regard for the long-term effect and without consultation with the industry."6 The law of supply and demand will better regulate the price of oil in a free market, incentivize exploration, increase fuel efficiency, and provide for technological improvement. The U.S. government understood the importance of the oil industry to the nation's economic development, but felt, at least initially, a more hands-off approach to regulating it was appropriate in a free market economy.

American philosophy with regard to foreign oil was built upon three ideals. First, "the participation of the United States nationals in the development of world oil resources is in the interest of all nations and essential to our national security." Access to other nations' excess oil is of crucial importance to our national security. Second, "an effective oil policy should encourage access by our nationals to world oil resources on 
equal terms with other nationals, and stable agreements between foreign governments and private industry on a basis which will promote development by free enterprise methods." ${ }^{8}$ Free enterprise with equal access to all nations will most effectively develop the world's oil resources. Lastly, the government should encourage oil development by American corporations through diplomatic channels to reduce risks and permit U.S. companies to operate under foreign laws and customs. The federal government should not punish American companies that technically violate U.S. laws as long as they operate consistent with U.S. interests. ${ }^{9}$

The United States' welfare and prosperity require petroleum policies which encourage exploration and development. ${ }^{10}$ The government must implement policy to encourage strong domestic development and access to foreign oil to supplement U.S. requirements and provide for times of emergency. Building and maintaining a strong petroleum industry during peacetime ensures resources will be available during war. Therefore it is clearly in the interest of national security to encourage development of petroleum reserves at home and abroad. As stated in the 1949 Report of the National Petroleum Council, "Withholding from development of the oil on public lands or in offshore areas, with the thought that it can be used in an emergency is not sound policy in terms of national security. The oil can be made available only by continuous and prolonged peacetime development."11 Barring areas such as the Alaskan National Wildlife Refuge and off-shore locations from drilling is contrary to our national interest as it takes decades to cultivate the resources and America could not react quickly to develop these areas if overseas sources were cut-off without warning. 


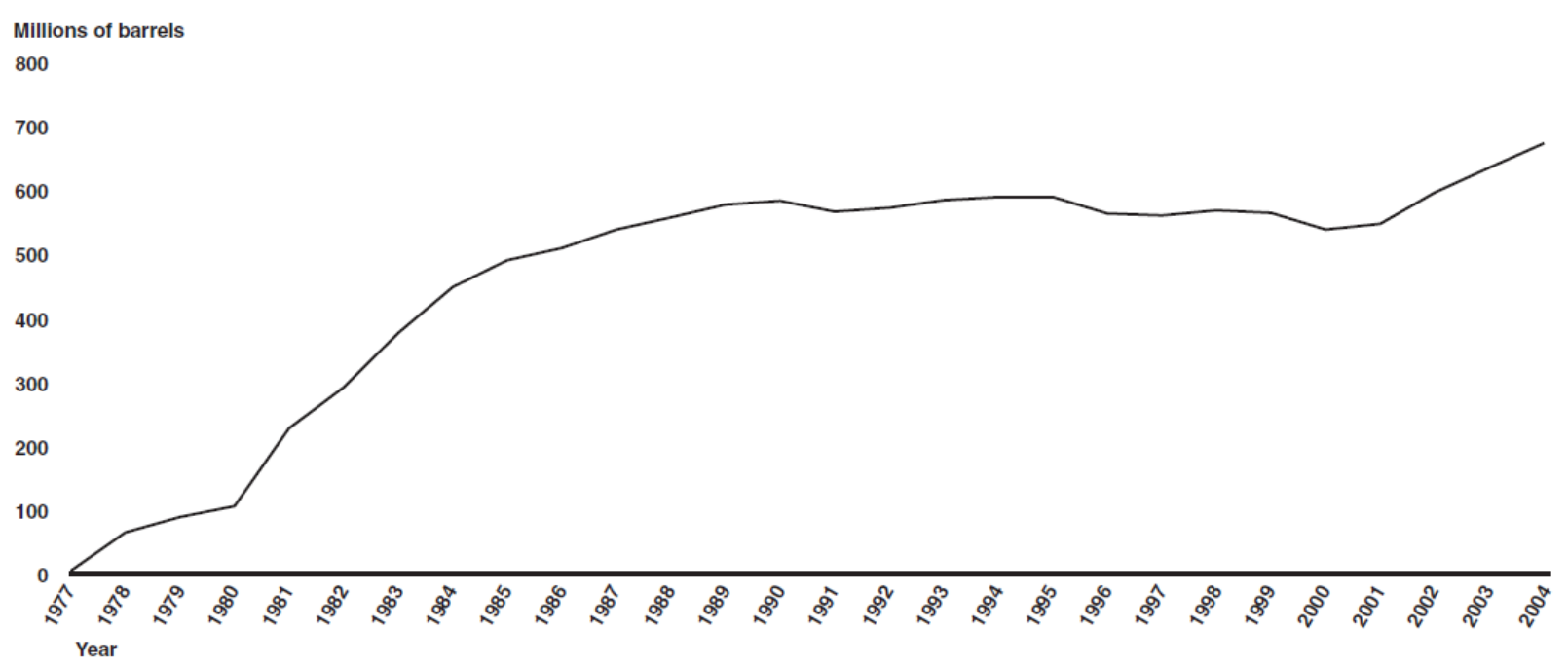

Figure 1: Strategic Petroleum Reserve Inventory over Time ${ }^{12}$

Access to oil was so important to national security that the government as early as 1949 felt America needed a strategic reserve. The National Petroleum Council stated, "The government should accumulate such inventories of petroleum products in peacetime as would be needed by the armed services in the early stages of a conflict." ${ }^{13}$ However, the Council did not feel massive stockpiles were necessary as rationing and increased domestic production could meet wartime demands. When Egypt blockaded the Suez Canal in 1956-57, the United States had adequate oil reserves and excess production capacity to ensure global demands were met. In the 1940s and 1950s this may have been true; however, today, given only 10 million barrels per day (MBD) domestic production with 19 MBD required to maintain the U.S. economy, a more substantial strategic stockpile is needed. Two years after the second 'oil crisis' that took place in 1973 Congress authorized the Strategic Petroleum Reserve (SPR), then started filling it in 1977 (see Figure 1 above). In the event all access to foreign oil is cutoff, the SPR's current 700 million barrels of oil will provide over two months' supply at today's usage rates. The world has changed and oil imports are far more important to 
the U.S. economy than in the past. Protecting both the domestic and foreign oil supply is clearly in the United States' national interest.

Since access to imported oil is so vitally important, the United States has demonstrated a willingness to spend a considerable amount to protect the supply and its transportation across the global commons. Studies estimate the annual U.S. cost to protect the global oil market as high as 143 billion dollars, in 2009 dollars. ${ }^{14}$ Table 1 details the direct military cost by individual services, but does not include indirect costs, hidden costs such as intelligence gathering, or other government agencies' expenses which contribute to securing the global commons. To protect the entire "global system of trade and travel that we know as 'globalization'" the U.S. spends 600 billion dollars a year. $^{15}$

\begin{tabular}{llcc}
\hline Unit & Force & $\begin{array}{l}\text { Cost per Unit } \\
\text { (billions, FY09) }\end{array}$ & $\begin{array}{l}\text { Potential Savings } \\
\text { (billions, FY09) }\end{array}$ \\
\hline Army division-equivalents & $22 / 3$ & 9.47 & 23.8 \\
USN carrier strike groups & 2 & 14.84 & 29.7 \\
USAF fighters and bombers & 344 & 0.04 & 12.7 \\
Total & & & 67.5 \\
\hline
\end{tabular}

Table 1: Cost of Forces Focused on Protecting the Global Flow of Oil ${ }^{16}$ Maintaining a robust worldwide petroleum industry with ongoing research and development leads to strong U.S. and global economies able to fund and maintain a powerful military to secure U.S. vital interests. "A major national security concern for the U.S. policymakers is the potential for an abrupt reduction in the supply of oil and a corresponding large increase in the price to result in a sharp fall in economic output. Such a decline would undermine U.S. national security, for example, by weakening U.S. 
global economic and political influence and the ability of the United States to pay for U.S. military forces. ${ }^{17}$ The increased cost of oil leads to severe economic hardship and a corresponding increase in the cost to maintain the U.S. military abroad. Increased costs limit the military's ability to accomplish its primary mission and degrade its ability to defend vital interests. Lower oil prices benefit consumers and, "by releasing funds for other purposes, provides potential benefits to U.S. national security by making defense dollars go further or boosting U.S. economic activity." ${ }^{18}$ Stability in the Middle East helps maintain a stable global oil market and leads to U.S. prosperity and security. Therefore, the United States has been interested in maintaining stability in the Middle East since World War I.

\section{Middle East Relations}

In World War I the Ottoman Empire, which controlled the Middle East, entered into an alliance with Germany. The Germans and Ottomans were largely successful attacking British in the Suez Canal zone and defeating Allied forces at Gallipoli in

1915. ${ }^{19}$ After Britain promised Sharif Husayn ibn 'Ali of Mecca an independent Arab state in return for support against the Ottomans and Germany, the Arabs revolted against Ottoman rule and supported the Allies. However, the Allies failed to uphold their end of the bargain, and the Arabs felt they were handed "a startling piece of doubledealing." 20

Following WWI the Europeans reestablished or maintained colonies in the Middle East, exploiting the nations for their resources. The colonial powers also drew territorial boundaries for states throughout the region without concern for language or culture. Further compounding matters, after WWII the Europeans and the United States agreed 
to establish an independent Jewish state of Israel. The United States actively supported Israeli independence and quickly recognized it as a sovereign nation. These and the issue of control of Palestine led to a host of problems in the region. The United Nations, with heavy U.S. influence, partitioned Palestine into Jewish and Arab states. At the time the Arabs owned most of the land, leaving the Jews no choice except to "fight for the land allotted to them by the UN's Partition Resolution." 21

In the eventual war, Israel defeated her Arab opponents from Lebanon, Syria, Iraq, Transjordan and Egypt for many reasons. Israel had vastly more experience coming out of WWII, stockpiled weapons and munitions, unity of purpose in wanting to establish a Jewish homeland, and numerical superiority. The Arab states were largely divided, had an inadequate number of soldiers and lacked sufficient military training or experience. The United States worked with the United Nations to bring about an ArabIsraeli cease fire and resettle hundreds of thousands of Palestinian refugees. The formation of Israel and the defeat of Arab armies in Palestine destabilized the fledgling Arab states.

Up to this point the primary U.S. interests in the Middle East were economic in trying to develop access to resources. As noted by John J. McCloy during Congressional testimony in hearings before the Subcommittee on Multinational Corporations of the Committee on Foreign Relations, the U.S. government "did everything they could to encourage American oil companies to enter this new area [the Middle East] so as to protect and supplement our own reserves which had been severely drained and, as a result of this foresight, oil did flow at reasonable prices, as I 
said, to the free world and it continued to do so for a long time. For a long period we had a stable period of supply and prices." ${ }^{22}$

In the 1950s the United States was in a position to stabilize world oil markets through increased domestic production and oil exportation. Following the oil crisis of 1956-57 where Egypt nationalized the Suez Canal blocking global oil shipments, the United States acted unilaterally to solve the problem by increasing domestic production and releasing reserves onto the global market. "Because the United States had access to large, readily available domestic reserves, it could compensate for international dislocations and stabilize supplies." ${ }^{23}$

Following WWII the United States' primarily concern was not stabilizing global supply, but countering and containing Soviet expansion into the Middle East through support to Israel. Over the years U.S. support to Israel served as a friction point with Arab nations. American arms sales to both Arabs and Israelis were viewed with skepticism and seen as destabilizing by their respective adversaries. In the early 1970s as demand increased, U.S. domestic oil production peaked, and the United States became a petroleum importing nation, America discovered it was hostage to overseas oil suppliers. This brought relations with the Arab oil producing nations to the forefront of U.S. politics.

G. John Ikenberry, Professor of Politics and International Affairs at Princeton University, explained in his book, Reasons of State: Oil Politics and the Capacities of American Government, "October 17, 1973, the day of the Arab OPEC embargo, was 'energy Pearl Harbor day'. In response to the outbreak of war between Israel, Egypt, and Syria, the Arab members of OPEC announced an embargo on oil shipments to 
countries supporting Israel." ${ }^{24}$ The oil shortage shocked the United States with high fuel prices, long gas lines, increased inflation and an economic down turn. Following this crisis "the United States attempted to balance its stated commitment to Israel with other regional commitments and interests." ${ }^{25}$ The United States sought to maintain support for Israel while preserving "relations with Arab states upon whom the United States was increasingly reliant for oil." ${ }^{26}$ To negotiate a permanent end to hostilities in the region, Secretary of State Henry Kissinger traveled heavily between belligerent countries and the United States conducting his world-renowned 'shuttle diplomacy.' With Soviet assistance, the United States was able to help establish and maintain a shaky peace in the region.

President Carter declared security of the Persian Gulf oil production a vital national interest as access to the region was a premium. Fearing another oil embargo, the United States tempered its interests and activities in the Middle East. The United States continued to support Israel, but worked to maintain a semblance of neutrality in the region. Following the Iraqi invasion of Kuwait, the United States built a coalition with Arab nations before going to war with Iraq, an Arab nation. To maintain the Arab coalition the United States went to great lengths to keep Israel out of the fighting-stationing multiple Patriot Batteries in Israel to protect against Iraqi scud missiles. Through great efforts the United States managed to keep Israel out of the fight, hold the Arab coalition together, accomplish the mission of ejecting Iraqi forces out of Kuwait, and keep the oil flowing to the western world. Maintaining a peaceful coexistence with much of the Middle East to keep the oil flowing in order to satiate the voracious appetites of the West is a difficult foreign policy. Even if successful, it fails to address 
the true problem the United States must solve: how to reduce consumption and establish an effective energy policy.

The Problem - Consumption \& Ineffective Policy

The United States is the largest energy consumer in a world where "the demand for fossil fuels is increasing while many studies indicate that fossil fuel reserves may be decreasing, based upon actual consumption data and growth forecast models."27 America's demand for oil has steadily risen since 1949 from 5 MBD to 19 MBD which equates to one-fourth of global consumption. These 19 million barrels of oil represent about $40 \%$ of the United States' overall energy consumption as detailed in Figure 2 below. The transportation sector alone utilizes $65 \%$ of America's petroleum. Therefore, transportation consumes one-fourth of the United States' overall energy and two-thirds of the oil. The United States cannot gain energy independence until she weans the transportation sector off oil.

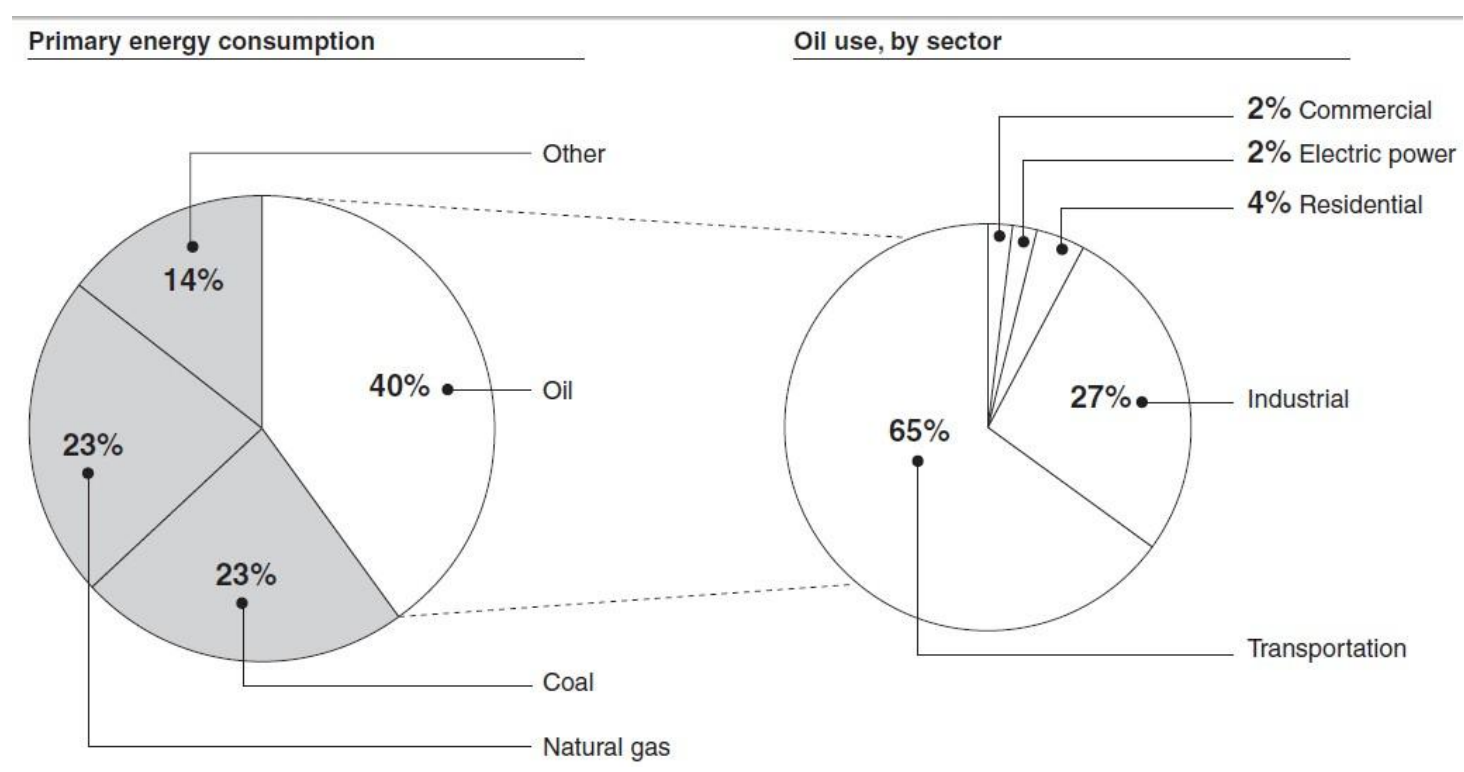

Figure 2: Breakout of United States energy consumption and oil use by sector. ${ }^{28}$ 
Currently more than half of U.S. petroleum consumption is satisfied with foreign oil as detailed in Figures 3 and 4. Some experts predict U.S. demand will hit 27 MBD as early as 2020 which will force America to import more than two-thirds of its required petroleum. ${ }^{29}$ To meet this demand, the United States must increase domestic production, reduce consumption and/or transition to alternative fuels. The alternative is massive increases in global oil production to meet unchecked demand.

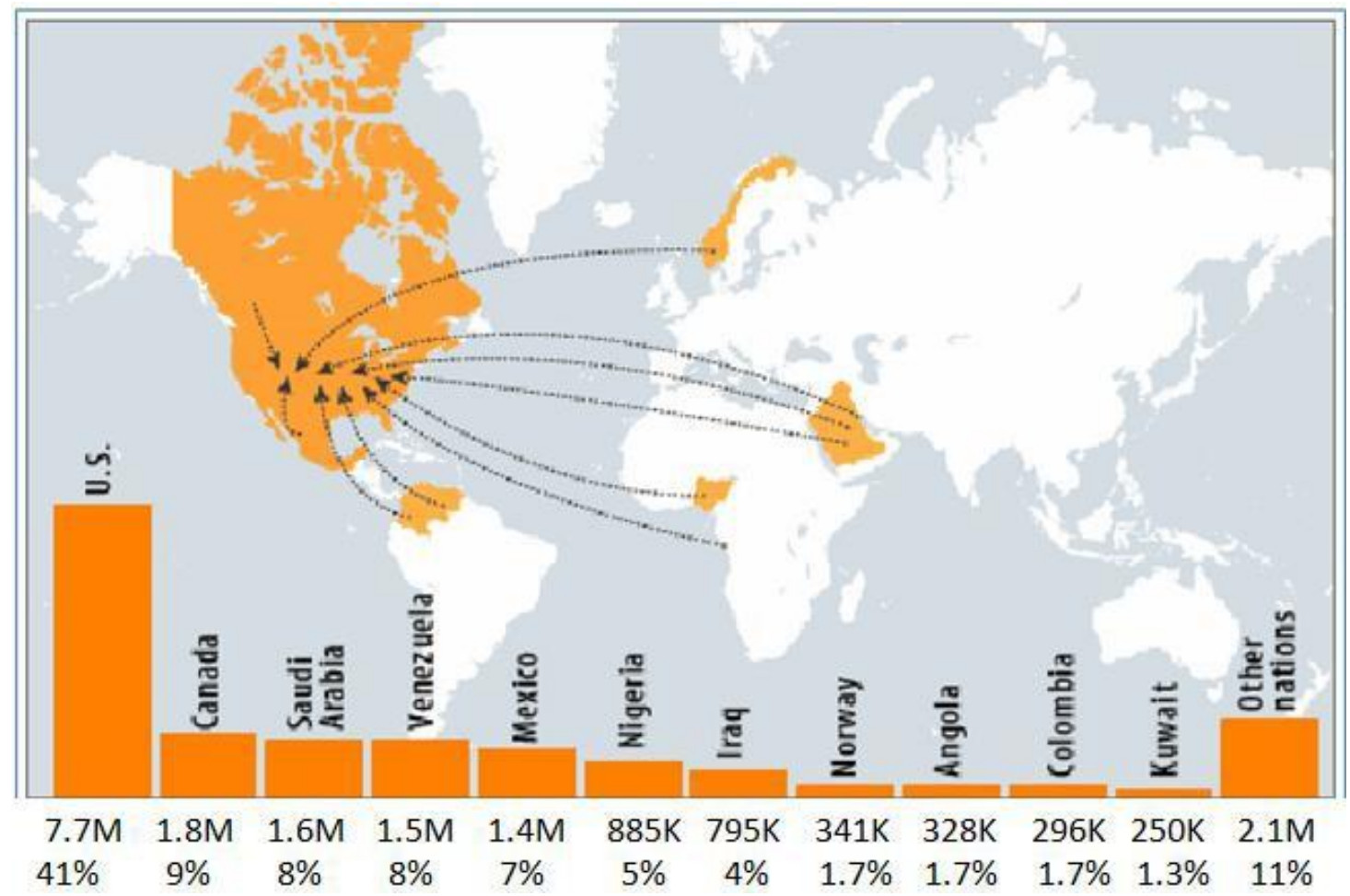

Figure 3: Breakout by country of U.S. petroleum suppliers. ${ }^{30}$

Global oil suppliers must increase production $1.3 \%$ per year to meet conservatively projected worldwide energy demands into the 2030s. ${ }^{31}$ Michael T. Klare, a Five Colleges Professor of Peace and World Security with appointments at Amherst, Hampshire, Mount Holyoke, and Smith Colleges and the University of Massachusetts, has written widely on global resource politics and estimates petroleum demand will increase $53 \%$ over the next 25 years. ${ }^{32}$ By some estimates oil requirements could jump 
from 86 million barrels per day (MBD) to as high as 130 MBD. Petroleum production will be hard pressed to meet this expected demand even with the most optimistic production scenarios and enhanced recovery methods. ${ }^{33}$ Based on current projections, global production will peak at $100 \mathrm{MBD}$ in 2030 , leaving a $30 \mathrm{MBD}$ shortfall. ${ }^{34}$ To meet this demand, countries must discover new sources of oil and OPEC would have to achieve the impossible and double its current production. New sources are possible, but present high risk and take a decade or longer to develop the necessary infrastructure. None of the OPEC nations, "except perhaps Saudi Arabia, is investing sufficient sums in new technologies and recovery methods to achieve such growth. Some, like Venezuela and Russia, are actually exhausting their fields to cash in on the bonanza created by rapidly rising oil prices." ${ }^{35}$ OPEC nations also have an interest in limiting production to conserve their supplies and keep global prices and thus profits high. ${ }^{36}$ Even in the best case scenarios global demand will exceed production by $10 \mathrm{MBD}$ resulting in higher prices and increased pressure to reduce demand or find alternatives for petroleum.

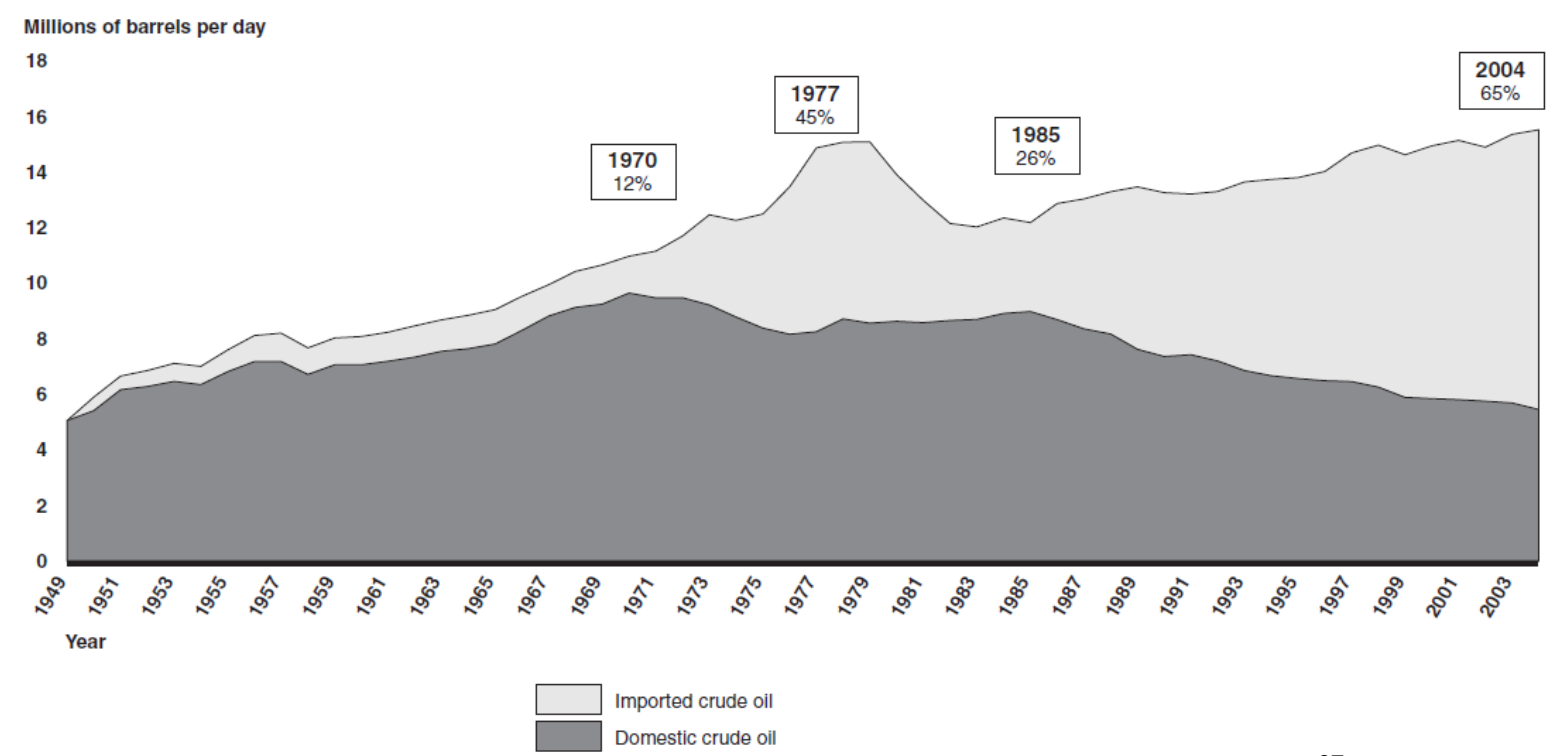

Figure 4: U.S. Oil Consumption of Domestic and Imported Crude Oil. ${ }^{37}$ 
Compounding the supply limitations, ineffective petroleum or energy policy and insufficient Corporate Average Fuel Economy (CAFE) standards are two reasons for unchecked demand and the inability to wean the transportation sector off oil. Oil dependency has been at critical levels since the 1970s, but Congress failed to enact sufficient legislation or fund adequate research and development into alternative fuels. Over the past 32 years Congress raised the CAFE standard only 6.9 miles per gallon (mpg), from 17.2 to $24.1 \mathrm{mpg}$ (see Table 2 below). In addition the CAFE standards, which were originally intended to improve fuel economy, contain loopholes for trucks, vans, minivans and Sport Utility Vehicles making them essentially useless. ${ }^{38}$ The everpowerful 'Oil Lobby' in Washington DC works overtime to keep Congress from legislating alternatives to oil as this would cut profits and, they argue, hurt the economy. ${ }^{39}$ America must break the Oil Lobby's bonds, cure the country's 'addiction to oil,' and implement policies to cut consumption and develop alternative fuels.

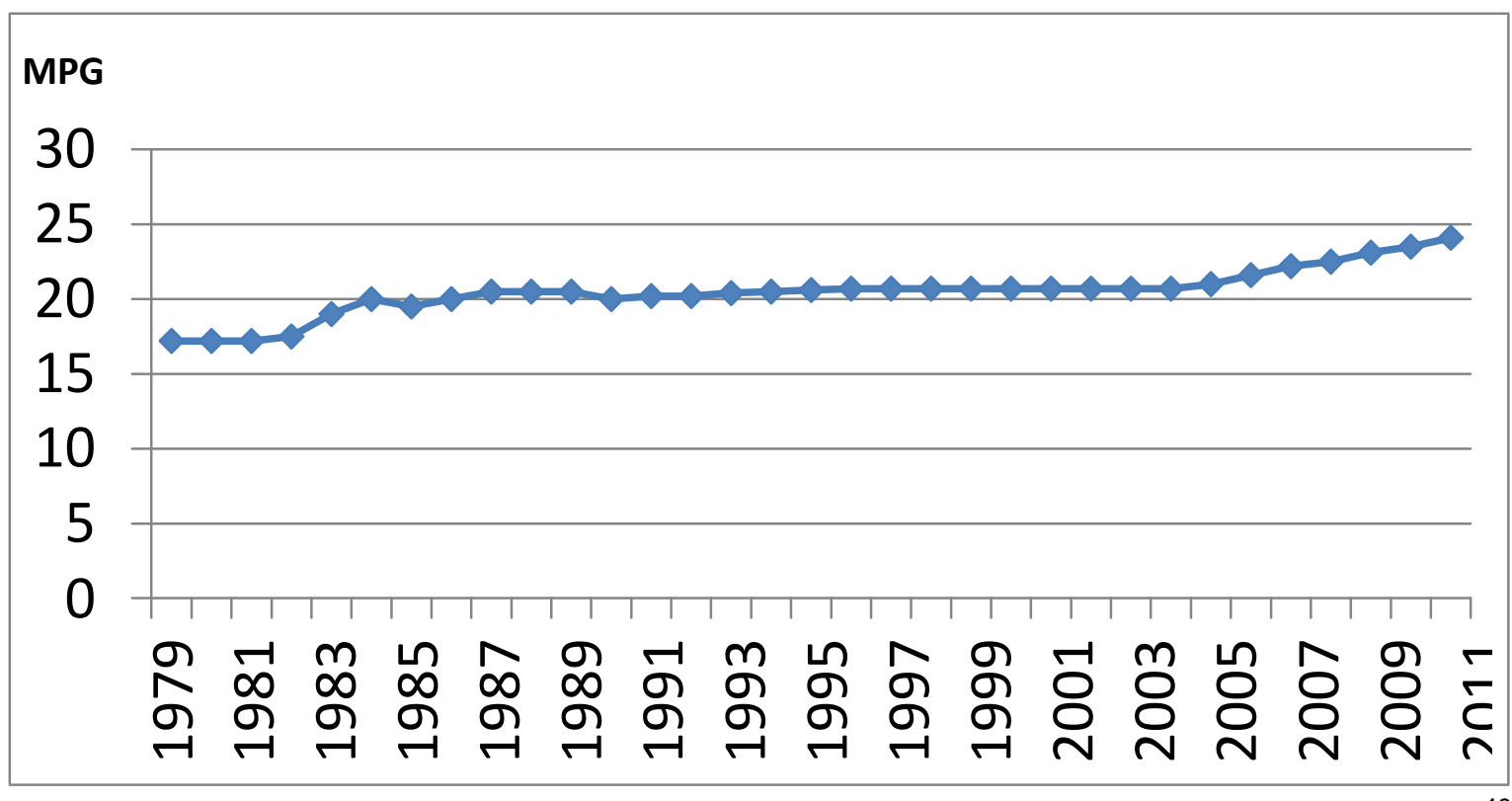

Table 2: U.S. Corporate Average Fuel Economy standards since inception ${ }^{40}$ 
$\underline{\text { The Way Ahead - Solution }}$

In 1970 the United States switched from being a petroleum exporting nation to a petroleum importing nation. Dependence on oil makes America vulnerable to OPEC and other oil exporting countries. "Oil producers might sway American Allies to support positions or remain neutral on certain issues with the promise of an uninterrupted petroleum supply, a reduced price, or subsidy for their allegiance. ${ }^{, 41}$ As demand for petroleum increases so, too, does the oil producer's control over consumer nations such as the United States. The United States must either secure more petroleum from its own resources or reduce its appetite for oil in order to throw off these Middle Eastern bonds and gain greater foreign policy freedom. This next section examines multiple options with varying degrees of feasibility and acceptability to reduce both America's reliance on oil and, subsequently, OPEC's influence over U.S. policy.

Increase Domestic Production. Increasing domestic petroleum supplies appears feasible on the surface. The United States could open the Alaskan National Wildlife Refuge (ANWAR) to drilling, increase off-shore drilling and invest heavily into shale oil or other technologies such as state-of-the-art injection techniques to increase production. In the recent past, however, numerous political action committees and environmental organizations have successfully blocked expanding U.S. oil exploration and production. Overcoming aggressive environmental organizations and intense political opposition would be extremely difficult in light of environmental tragedies such as the 1989 Exxon Valdez oil spill in Prince William Sound, Alaska or the 2010 Deepwater Horizon "BP" oil spill in the Gulf of Mexico. Exxon spilled 11 million gallons of oil in the Alaskan waters. ${ }^{42}$ British Petroleum released nearly five million barrels (205 
million gallons) of oil into the Gulf of Mexico. ${ }^{43}$ Further, although the U.S. oil industry has the physical capability to increase domestic production, it still could not meet the current or projected demand without foreign imports, and overcoming the environmental and political obstacles would be very difficult, if not impossible.

Beyond the environmental issues, the U.S. reserves may not support increased production. Michael Klare cited various 2011 U.S. Department of Energy data stating the United States has less than 25 years known petroleum reserves accessible or not. ${ }^{44}$ "Within the United States the hectic and disorganized drilling for new oil had often used up reserves prematurely." ${ }^{45}$ For this reason, given Klare's estimates, increasing domestic production to the levels required to replace Middle East oil could exhaust U.S. reserves in 10-15 years spawning an energy crisis decades earlier than anticipated. ${ }^{46}$ Therefore, even in the unlikely event politicians and environmentalists relented, the United States does not appear to have enough petroleum reserves to meet current and projected demand. Even if sufficient reserves do exist it takes a decade to develop them which is too slow to respond to a crisis such as shipping disasters or another oil embargo. Given these issues, U.S. policy-makers should focus more on reducing consumption.

Reduce Consumption. Reducing U.S. petroleum consumption is the most feasible and timely solution available. There are multiple options to reduce petroleum consumption in the United States: Congress could enact public policies to encourage telework or alternative forms of transportation; politicians could increase the gasoline tax to reduce consumption; and our leaders could mandate higher fuel efficiency standards for all vehicles. 
Policy. Politicians could implement immediate measures to curb usage. They could incentivize use of car pools and mass transit. Through simply mandating all government employees and contractors to utilize mass transit or car pools, where available, the United States could immediately cut $5 \%$ of its overall petroleum usage. ${ }^{47}$ Adding tax incentives for other individuals who ride share or use public transportation could double these savings. Although easily implemented, such measures may prove unpopular with employees accustomed to the freedom of driving to and from work. A less controversial option is telework.

By teleworking, working from home or from a Telework center close to home, Americans could save thousands of dollars on fuel and vehicle maintenance and significantly reduce highway congestion. Assuming only one-fourth of U.S. workers could telework one day per week, this would still result in nearly a $5 \%$ reduction in overall gasoline consumption. ${ }^{48}$ This also significantly reduces highway congestion and the amount of vehicles idling waiting for traffic saving additional fuel. Telework appears a less risky option as it doesn't confront the powerful Oil Lobby and offers incentives for non-government employees and employers. With mandatory government telework programs and commercial incentives to encourage employees and employers alike to shift to telework, the United States could cut gasoline consumption between 10-15\% and significantly reduce highway congestion in a period of a few months. ${ }^{49}$

Taxes. Another potential solution to curb usage is increasing the gasoline tax. Raising the current federal fuel tax from 18.4 cents for gasoline and 24.4 cents for diesel fuel to two to four dollars or more per gallon would bring U.S. pricing in line with European fuel costs. Higher fuel prices would likely lead to energy conservation by 
encouraging people to travel less and purchase more fuel efficient vehicles, such as a 50 mpg Prius or electric cars such as the Nissan Leaf or Chevy Volt. Increased fuel prices would also encourage mass transit usage as evidenced by the extent to which people flocked to the subway and buses when prices spiked in $2008 .{ }^{50}$ Although very unpopular, increased fuel taxes would place transportation maintenance costs for roads and bridges upon those who use them. ${ }^{51}$ In the past the Oil Lobby has adamantly opposed any fuel tax increases as this would cut their profit margin. Therefore, supporters of tax increases would have to be prepared to pre-empt and counter inflated or false propaganda designed to generate opposition. However, if increased gasoline taxes managed to double the use of mass transit they would cut petroleum usage an additional $5 \%$ overall with results visible in a few months. ${ }^{52}$ The government may need to increase mass transit funding to meet increased demand, but could use gas tax revenues and reallocate some transportation dollars from road construction due to reduced highway usage.

Increased fuel efficiency. The government might possibly assist the transition to more fuel efficient vehicles by offering tax incentives to manufacturers or consumers who purchase them. Doubling fuel efficiency standards, which is currently achievable with the Prius and Volt, would cut gasoline usage in half and would equate to an overall $25 \%$ reduction in U.S. oil consumption. ${ }^{53}$ Mandating higher fuel-efficiency standards such as $50,75,100$ and $125 \mathrm{mpg}$ phased in every two to three years could eliminate the need for foreign oil within 15 years as consumers traditionally replace $7 \%$ of the nation's vehicles each year. The 2009 Loremo, produced in Germany, proves the naysayers wrong regarding the limits of fuel efficiency. The Loremo entered the 
European market in 2009 sporting 157 mpg in a four-passenger two-cylinder turbo diesel for a mere 15,000 Euros or $\$ 22,000 .^{54}$

Although doubling or even quadrupling CAFE standards is feasible with current technology it may prove difficult to implement due to stiff opposition. First, auto manufacturers will likely attempt to block any dramatic CAFE increases claiming the costs to retool factories is too high, resulting in lost jobs and a depressed economy. Next, doubling fuel efficiency will reduce the demand for oil, the price of oil and company profits. The Oil Lobby strongly opposes any legislation which portends to impact their bottom-line. Finally, many Americans feel it's their right to drive fast gasguzzling cars and sport utility vehicles (SUV). Soccer moms will find it difficult to give up their big SUVs for fuel-efficient diesel minivans claiming their SUVs are much safer in the event of an accident. Successfully implementing fuel efficiency policy will require its proponents to overcome two powerful political lobbies as well as Americans' current infatuation with big, 'safe' SUVs. In addition to making vehicles more efficient, Americans could run them on alternative fuels.

Alternative fuels. Alternative, environmentally safe fuels are popular with environmentalists and politicians alike. Some analysts argue that investing heavily in alternative fuels could potentially supplant petroleum for all uses entirely within 20 years. Bio-fuels generated from algae, corn, soy beans, caster beans and a host of other renewable sources could replace gasoline and diesel fuel. However, using corn to produce ethanol could result in higher food prices, and it currently takes more energy to produce a gallon of ethanol than is generated. ${ }^{55}$ Also, cars cannot presently run on pure ethanol, requiring $85 \%$ petroleum. Bio-diesel offers more opportunity. 
Bio-diesel is a more viable option as manufacturers can use everything from algae or soy beans to used vegetable oil from fast food restaurants to produce it. Current diesel engines are fully compatible with bio-diesel; therefore it could immediately replace diesel fuel in semi-trucks, buses, automobiles, and industrial equipment ${ }^{56}$ For the past few years the city of Las Vegas, Nevada has run nearly every diesel vehicle on bio-diesel with excellent results; reduced emissions $22 \%$, cut maintenance costs $16 \%$ and increased fuel efficiency by $2 \%$ overall. ${ }^{57}$ Mandating $50 \%$ bio-diesel usage for all industry, automobiles and trucking with no waivers except for DoD combat vehicles could reduce overall U.S. petroleum use by $20 \%$ across the transportation and industrial sectors combined. Transition to $100 \%$ bio-diesel would double the savings and by itself nearly eliminate the requirement for any oil imports. The United States has the farming and manufacturing capacity to produce this fuel today.

Bio-fuels offer tremendous gains with few drawbacks. Additional research and development is needed to keep costs down. If Congress maintains the bio-diesel subsidies, prices will remain competitive with diesel fuel mitigating many consumers' complaints about going green costing too much at the pump. As with most manufacturing, mass production offers efficiencies which will lower prices further, negating the requirement for government subsidies. Bio-diesel is just one renewable energy source among many alternatives.

Alternative and Renewable Energy Sources. Solar, wind, and water are available in abundance. In addition to freeing the transportation sector from its oil dependence, alternative and renewable energy is capable of eliminating oil-based electricity production. These alternatives could also reduce all fossil fuel electric 
requirements—cutting petroleum imports, conserving natural gas and coal, and reducing green house gases benefiting the environment.

Water or hydroelectric power, to examine just one alternative, has some of the highest electricity generating potential in the world which could eliminate oil electric plants and significantly reduce coal electric generation. To date only one-third of the exploitable U.S. rivers and water sources are utilized to generate power. Of the dams currently constructed, only $10 \%$ in North America are used to generate electricity leaving a lot of room for expansion and development. If existing dams and other available water sources were developed, "the hydroelectric potential could have produced half the world production." 58 There are drawbacks with hydroelectric power, such as competing water usage, reliability concerns in times of drought and displacing people to build dams or reservoirs; however, the United States cannot ignore the vast energy potential. Hydroelectric power could easily replace the $2 \%$ of oil consumption utilized for electric generation and has multiple environmental benefits over oil, coal or natural gas electric production.

Solar, wind, and water electric generation could easily provide $15-20 \%$ of power requirements within 20 years with modest investment. Unfortunately, projects "to harness wind, waves, or solar energy—had been made thoroughly unprofitable by the lower oil price." ${ }^{59}$ Klare estimates U.S. energy requirements will go up at least $10 \%$ over the next 25 years. ${ }^{60}$ Historically lower oil prices and unprofitable research projects set back alternative energy research and development decades. Therefore, even the generous estimates above fall short of projected demand. Consequently, without 
considerable investment above current or planned levels renewable energy will not solve the United States' energy dilemma.

Conclusion

America's increased demand for foreign oil has placed her at the mercy of oil producing nations and hampered or limited U.S. policy options with regard to the Middle East. Although some of the policy options just discussed seem drastic, they are all feasible to some degree and full implementation could cut oil consumption in half which would bring overall U.S. consumption to within current domestic petroleum production capacity. Therefore, the solution to the U.S. oil addiction is to do a combination of all of the above. Only through attacking the problem from multiple angles simultaneously will the nation overcome the powerful political lobbies and achieve true energy independence. Implementing policy to conserve fuel while concurrently improving fuel efficiency will double the benefits. Increased utilization of bio-diesel fuel with a gradual shift to diesel automobiles could eliminate the entire Transportation and Industrial sectors cutting $80-90 \%$ of the nations' petroleum usage. This would eliminate the need for any foreign oil, free the United States from outside influence and give the nation greater control over national security and foreign policy.

Ten years of full implementation of the above recommendations could result in a new world. A typical day would involve driving to work in an electric or $150+$ mpg turbodiesel vehicle or riding on public transportation powered by electricity or bio-diesel. Safe, modern nuclear power plants, new hydro-electric dams and solar or wind power plants will provide the electricity running the United States. Pollution from petroleum, coal and natural gas is dramatically reduced or non-existent. The United States will still 
require oil for manufacturing and a few other uses. Domestic oil production will far exceed demand negating the need for importing any foreign oil. Oil manufacturers will have converted most of their capacity to production of synthetic and bio fuels. The economy will flourish and the U.S. military will continue to patrol the global commons, but at much lower costs and without caving to foreign oil producing nations' interests. In short, the United States will follow its vital interests without the threat of an oil embargo.

\section{Endnotes}

${ }^{1}$ G. John Ikenberry, Reasons of State: Oil Politics and the Capacities of American Government (New York, Cornell University Press, 1988): 48

${ }^{2}$ Anthony Sampson, The Seven Sisters (New York, Bantam Books, 1991): 76.

${ }^{3}$ J. H. A. Bone, Petroleum and Petroleum Wells (J.B. Lippincott \& Company, Philadelphia, 1865). Quoted in Anthony Sampson, The Seven Sisters (New York, Bantam Books, 1991): 29.

${ }^{4}$ A National Oil Policy for the United States: A Report of the National Petroleum Council (1949): 1 .

${ }^{5}$ Ibid., 3.

${ }^{6}$ Ibid., 5.

${ }^{7}$ Ibid., 16.

${ }^{8}$ Ibid., 17.

${ }^{9}$ Ibid: 19.

${ }^{10}$ lbid., 19.

${ }^{11}$ lbid., 21.

${ }^{12}$ GAO, Report to Congressional Requesters: Strategic Petroleum Reserves: 18

${ }^{13}$ A National Oil Policy: 21.

${ }^{14}$ Keith Crane, Imported Oil and U.S. National Security (RAND, 2009): 63.

${ }^{15}$ U.S. Joint Forces Command, Joint Operating Environment 2010 (March 2010): 22

${ }^{16}$ Keith Crane, Imported Oil and U.S. National Security (RAND, 2009): 71. 
17 lbid., 19.

18 lbid., 24.

${ }^{19}$ Eugene Rogan, The Arabs (New York, Basic Books, 2009)

${ }^{20}$ lbid., 153

${ }^{21}$ lbid., 253

22 John J. McCloy, testimony in hearings before the Subcommittee on Multinational Corporations of the Committee on Foreign Relations, (U.S. Senate, 93d Congress, 2d Session, part 5, 24 January 1974): 65

${ }^{23}$ G. John Ikenberry, Reasons of State: 82

24 lbid., 3

${ }^{25}$ Clyde R. Mark, Israel-United States Relations, Congressional Research Service (17 October 2002)

${ }^{26}$ Steve Jones, U.S. Foreign Policy in the Yom Kippur War: The Beginning of Shuttle Diplomacy. http://usforeignpolicy.about.com/od/middleeast/a/U-S-Foreign-Policy-In-The-YomKippur-War-1973.htm (accessed December 23, 2011).

${ }^{27}$ Robert W. Weaver, Gasoline: The Achilles Heal of U.S. Energy Security (USAWC, 20 March 2010): 1.

${ }^{28}$ United States Government Accountability Office, Report to Congressional Requesters: Strategic Petroleum Reserves - Available Oil Can Provide Significant Benefits, but Many Factors Should Influence Future Decisions about Fill, Use, and Expansion (August, 2006): 11

${ }^{29}$ PBS.org, "Where Does U.S. Oil Come From?" http://www.pbs.org/frontlineworld/stories/colombia/images/map.swf (accessed December 22, 2011).

${ }^{30} \mathrm{GAO}$, Report to Congressional Requesters: Strategic Petroleum Reserves: 12

${ }^{31}$ U.S. Joint Forces Command, Joint Operating Environment 2010 (March 2010): 24

${ }^{32}$ Michael T. Klare is a Five Colleges Professor of Peace and World Security, a joint appointment at Amherst, Hampshire, Mount Holyoke, and Smith Colleges and the University of Massachusetts. Klare has written widely on security affairs, arms control, and global resource politics. He is the author of Resource Wars, Blood and Oil, and Rising Powers, Shrinking Planet. In addition to his books, Klare has also written articles for Foreign Affairs, The Nation, Newsweek, and he is a contributing editor of Current History. Michael T. Klare, "The Great Energy Struggle," lecture with Q \& A, Carlisle, PA, Dickinson College, November 9, 2011.

${ }^{33}$ U.S. Joint Forces Command, Joint Operating Environment 2010 (March 2010): 24

${ }^{34}$ Ibid., 29 
${ }^{35}$ Ibid., 26

${ }^{36}$ lbid., 27

${ }^{37} \mathrm{GAO}$, Report to Congressional Requesters: Strategic Petroleum Reserves: 12

${ }^{38}$ Wikipedia, Corporate Average Fuel Economy, http://en.wikipedia.org/wiki/Corporate_Average_Fuel_Economy (accessed October 4, 2011).

39 Joshua Tickell, dir., Fuel, DVD (Hollywood, CA: Blue Water Entertainment, 2008).

${ }^{40}$ Wikipedia, Corporate Average Fuel Economy, http://en.wikipedia.org/wiki/Corporate_Average_Fuel_Economy (accessed October 4, 2011).

${ }^{41}$ Clayton K. S. Chun, "Do Oil Exports Fuel Defense Spending," Strategic Studies Institute, (February 2010): 1-2.

42 Environmental Protection Agency, "Exxon Valdez," January 27, 2011, http://www.epa.gov/osweroe1/content/learning/exxon.htm (accessed November 12, 2011).

43 Joel Achenbach and David Fahrenthold, "Oil well spilled out 4.9 million barrels, latest measure shows," Washington Post, August 3, 2010. http://www.washingtonpost.com/wpdyn/content/article/2010/08/02/AR2010080204695.html (accessed on November 13, 2011).

${ }^{44}$ Michael T. Klare, "The Great Energy Struggle," lecture with Q \& A, Carlisle, PA, Dickinson College, November 9, 2011.

${ }^{45}$ Anthony Sampson, The Seven Sisters (New York, Bantam Books, 1991): 92.

${ }^{46}$ Michael T. Klare, "The Great Energy Struggle”.

${ }^{47}$ Michael T. Klare estimated a significant savings through increased utilization of efficient rapid transit. Klare, "The Great Energy Struggle".

${ }^{48}$ Mathematical calculation given $1 / 4$ of all workers cutting their driving to work from 5 to 4 days per week. One day per week reduction equals a $20 \%$ reduction in driving. $0.25 \times .20=$ 0.05 or $1 / 4 \times 20 \%=5 \%$.

${ }^{49}$ Mathematical calculation given a $5 \%$ reduction in oil consumption for teleworking 1 day per week, it stands to reason increasing the percentage of American workers who telework or increasing from 1 day per week to 3 days per week will triple the savings to $15 \%$.

${ }^{50}$ Robert Rapier, "The Case for Higher Gas Taxes (and Lower Income Taxes)," The Oil Drum, December 15, 2008. http://www.theoildrum.com/node/4869 (accessed on 18 January, 2012).

${ }^{51}$ Michael T. Klare, "The Great Energy Struggle”.

${ }^{52}$ Mathematical calculation based upon Michael Klare's 5\% estimate for mass transit. Doubling mass transit usage would result in an additional $5 \%$ reduction in oil consumption. 
${ }^{53}$ Mathematical calculation: Approximately $50 \%$ the oil consumed in the United States is for automobiles. Cutting gasoline usage in half would result in an overall $25 \%$ savings in oil consumption. $0.50 \times 0.50=0.25$ or $50 \% \times 1 / 2=25 \%$.

54 Jacob Gordon, Loremo: The Low Resistance Mobile.

http://editorial.autos.msn.com/article.aspx?cp-documentid=457882 (accessed on December 24, 2011).

55 Joshua Tickell, dir., Fuel.

${ }^{56}$ lbid.

${ }^{57}$ National Biodiesel Board, Biodiesel Users: City of Las Vegas, Nevada. http://www.biodiesel.org/resources/users/stories/las_vegas.shtm (accessed on January 31, 2012).

${ }^{58}$ Leonardo Mangeri, Beyond the Age of Oil: The Myths, Realities, and Future of Fossil Fuels and their Alternatives (California, Praeger): 119

${ }^{59}$ Anthony Sampson, The Seven Sisters (New York, Bantam Books, 1991): 2.

${ }^{60}$ Michael T. Klare, "The Great Energy Struggle". 